\title{
CHROMIUM AND ZINC IN A SERIES OF PLANTS USED IN PORTUGAL IN THE HERBAL TREATMENT OF NON-INSULINIZED DIABETES
}

\author{
V. R. OSÓRIO E CASTRO* \\ Escola Superior Agrária de Castelo Branco (IPCB), 6000 Castelo Branco. Portugal
}

(Received: 13 September 2000; accepted: 18 June 2001)

\begin{abstract}
Chromium $\left(\mathrm{Cr}^{3+}\right)$ and zinc $\left(\mathrm{Zn}^{2+}\right)$ are essential micronutrients for humans. Chromium's main action is thought to be the regulation of blood sugar, because chromium deficiency is related with diabetic-like (type 2) symptoms, and chromium supplementation is associated with increased glucose tolerance and insulin sensitivity. Zinc supplementation also alleviates hyperglycaemia of the same type of diabetic patients contributing to improved insulin activity. Some Portuguese plants are commonly used as teas, alcoholic extracts or as powders by diabetic people and as medicines. Although their active principle is not yet known, the importance of their chromium and zinc content in the claimed therapeutic properties should not be disregarded. Thus, the determination of chromium and zinc in some Portuguese medicinal plants was performed by atomic absorption spectrophotometry. Almost all the analysed plants contain chromium and zinc at the normal level for these elements but many plants, which are used for the preparation of teas or other forms of remedies to help those type of diabetic patients, contain them in higher levels.
\end{abstract}

Keywords: chromium, zinc in plants, medicinal plants, antidiabetic plants

A requirement for chromium to assure normal glucose tolerance in rats was first observed by using the glucose tolerance factor (GTF), which is isolated from brewer's yeast or pork kidney (SCHWARTZ \& MERTZ, 1959). In human subjects trivalent chromium supplements improve glucose metabolism (ANDERSON, 1992).

A good supply of chromium is important to keep a daily intake of about $50 \mu \mathrm{g}$ (range 50-200 $\mu \mathrm{g}$ ) (ANDERSON et al., 1992). Lists of foodstuffs with known concentrations of chromium (ADRIAN, 1991), as well as selected foods have been published (ANDERSON et al., 1992). In Iraq, for example, bread from barley flour is traditionally used in the management of diabetes mellitus, and the high content of chromium $(5.69 \mu \mathrm{g} / \mathrm{dry} \mathrm{wt})$ in this flour was postulated to explain its beneficial effect (MAHDI \& NAISMITH, 1991).

* Fax: 351272 339901; E-mail: valdemar@esa.ipcb.pt 
Zinc has many different functions. It has been identified in over 200 enzymes, as a component of biomembranes with an important role in structure and function. It stabilizes some hormone receptor complexes, helps to stabilize the structures of RNA, DNA, ribosomes and transcription factors (KING \& KEEN, 1994). Alterations in zinc metabolism have been shown to occur in both diabetic humans and experimental animals: hypozincaemia is a relatively common finding in diabetes and $\mathrm{Zn}$ supplementation of diabetic patients has been reported to improve immune function (KING \& KEEN, 1994). Recommended zinc intake to maintain balance is about $15 \mathrm{mg}$ per day for adult males and $12 \mathrm{mg}$ per day for adult females (KING \& KEEN, 1994).

In Portugal some plants are consumed by type 2 diabetic people to alleviate their health problems. In popular medicine those plants are well known in relation to that therapeutic property, although the involved active principle is not known. Maybe compounds containing chromium and/or zinc could also be responsible for their pharmacological effect (FELCMAN \& TRISTÃO-BRAGANÇA, 1988; OsÓRIO E CASTRO, 1998). On this premise, some Portuguese plants, commonly employed to reduce sugar in the bloodstream and others without this property, were analysed for these elements, using atomic absorption spectrometry.

\section{Materials and methods}

\subsection{Instrumentation and analysis conditions}

For chromium determination a Shimadzu atomic absorption spectrophotometer (flameless atomic absorption spectrophotometer), model 6501, equipped with a Shimadzu graphite furnace, model 6FA-6000, a deuterium lamp background corrector and an autosampling system model ASC-6000 were applied in all determinations. As a light source, a hollow cathode lamp from Hamamatsu Photonics K.K. (Japan) was employed, and pyrolytic coated graphite tubes were used as atomisers.

The conditions for analysis were based on the instructions contained in the instrument manual. Samples of $10 \mu \mathrm{l}$ were carried to the graphite tube by the autosampling system and submitted to the furnace established conditions (Table 1). The remaining parameters (slit $=0.5 \mathrm{~mm}$, wavelength $=357.9 \mathrm{~nm}$ ) were set according to manual instructions.

For zinc determination a Shimadzu atomic absorption spectrophotometer, model 6501, was used. Parameters for flame atomic absorption spectrophotometer ( slit $=0.5 \mathrm{~nm}$, wavelength $=213.9 \mathrm{~nm} ;$ mode $=$ B.C.G.; fuel: acetilene, $21 \mathrm{~min}^{-1}$; oxidant: air, $1.51 \mathrm{~min}^{-1}$; burner: $10 \mathrm{~cm}$; burner height: $9 \mathrm{~mm}$ ) were set according to manual instructions with some modifications. 
Table 1

Furnace conditions for chromium analyses

\begin{tabular}{lccl}
\hline Stage & Temperature $\left({ }^{\circ} \mathrm{C}\right)$ & Time $(\mathrm{s})$ & Heat \\
\hline Drying & 120 & 10 & Ramp \\
Drying & 120 & 10 & Step \\
Ashing & 600 & 10 & Ramp \\
Ashing & 600 & 10 & Step \\
Atomization & 2400 & 3 & Step \\
Atomization & 2400 & 3 & Step \\
\hline
\end{tabular}

\subsection{Sample preparation}

Some plants were obtained from drug stores, others were collected in this School Farm and only the parts expected to be active were used. The first step in sample preparation was washing with bidistilled water to avoid contamination by dust and/or soil and drying at room temperature, followed by grinding in a porcelain vessel, always avoiding contact with stainless steel. The powder obtained was further dried at $75^{\circ} \mathrm{C}$ for $3 \mathrm{~h}$. Calcinations were performed by submitting $0.5 \mathrm{~g}$ of material at $500^{\circ} \mathrm{C}$ for $3 \mathrm{~h}$ (in triplicate) in a porcelain capsule. To the remaining ash $10 \mathrm{ml}$ of a mixture of suprapure $\mathrm{HCl}: \mathrm{HNO}_{3}: \mathrm{H}_{2} \mathrm{O}(1: 1: 8)$ was added, and after boiling for $2 \mathrm{~min}$ the cool solution was quantitatively transferred to a $25 \mathrm{ml}$ volumetric flask to be used without further dilutions. This procedure was performed (CURTIUS \& CAMPOS, 1982) and each sample was calcinated at least twice (always in triplicate) resulting in six acid solutions for repeated further analysis on different days.

\subsection{Chromium and zinc analysis}

Direct determination of chromium concentration in the prepared samples was performed comparing with aqueous standard chromium (Tritisol, Merck). A stock chromium solution $(50 \mathrm{ppm})$ was prepared and stored in a polyethylene container. Fresh working aqueous standards were made by volumetric dilution of the stock solution to the desired concentrations with deionized water. A calibration curve automatically prepared between 20 and $100 \mathrm{ppb}$ of $\mathrm{Cr}^{+3}$ was obtained $\left(\mathrm{r}^{2}=0.9948\right)$.

Direct determination of zinc concentration in the prepared samples was performed by comparison with aqueous standard zinc (1.000 $\mathrm{g} \mathrm{l}^{-1} \pm 0.002$, Panreac). A stock zinc solution $(1000 \mathrm{ppm})$ was prepared and stored in a polyethylene flask. Fresh working aqueous standards $(0,0.4,0.8,1.2,1.6,2.0 \mathrm{ppm})$, diluted to the desired concentrations with deionised $\mathrm{H}_{2} \mathrm{O}$, were used to get a calibration curve $\left(\mathrm{r}^{2}=0.9992\right)$. 
To check and validate the obtained results a reference powder plant (lichen material IAEA-336) was used, showing the expected values (in the 95\% confidence interval) for chromium and zinc.

\section{Results}

Chromium and zinc content of some plants with and without claimed type 2 antidiabetic properties were determined by using atomic absorption spectrophotometry (standard calibration method). Table 2 presents results for chromium content $\left(\mu \mathrm{g} \mathrm{g}^{-1}\right.$ dry wt), for a series of 21 plants almost all from Portugal, (leaves from fruit trees), a few of which are used in the herbal treatment of diabetes (type 2) and included the alga Fucus vesiculosus $\mathrm{L}$. It can be seen that chromium concentrations are between 0.2 (plant 21) and $7.5 \mu \mathrm{g} \mathrm{g}^{-1}$ dry wt (plant 1) and the median of the 21 plants $=1.6 \pm 1.7 \mu \mathrm{g} \mathrm{g}^{-1}$ dry wt. Two groups of plants can be defined on the basis of their chromium levels. One of them, plants 1, 2, 4, 6 and 9, claimed to have hypoglycaemic activity, have much higher concentration of chromium (median: $3.6 \pm 2.3 \mu \mathrm{g} \mathrm{g}^{-1}$ dry wt) than the others (median: $0.97 \pm 0.65 \mu \mathrm{g} \mathrm{g}^{-1}$ dry wt). Particularly, the plant Syzygium jambolanum (plant 1), a Brasilian plant normally transformed in an alcoholic solution, and the alga Fucus vesiculosus (plant 2), are claimed to have strong non insulinized antidiabetic properties. The plant and the alga have 7.5 and $5.0 \mu \mathrm{g} \mathrm{g}^{-1}$ dry wt of chromium, respectively, much more than the others described in Table 2. The other marked plants have also been referred to as antidiabetic ones and indeed their chromium content is in the range found for other hypoglycemic plants (OSÓRIO E CASTRO, 1998; FELCMAN \& TRISTÃOBRAGANÇA, 1988). Concerning their relatively high content of chromium, the plants Ficus carica (plant 3) and Corylus avellana (plant 5), at least, could, in principle, be accepted as important plants to diabetic people, if their content of chromium is important to have therapeutic effect, but such activity was not reported for them. Significant differences $(\mathrm{P}=0.05)$ were found for chromium content between the two groups of plants (antidiabetic plants 1, 2, 4, 6, and 9 compared with the remaining 16 plants).

As regards zinc content, 33 plants were analysed (leaves of aromatic plants and others, Table 3) showing zinc concentration values between 8 (plant 33) and $135 \mu \mathrm{g} \mathrm{g}^{-1}$ dry wt (plant 1 ) with the median value $=38 \pm 21 \mu \mathrm{g} \mathrm{g}^{-1}$ dry wt. This concentration range includes concentration values also found in other plants (SZENTMIHÁLYI \& THEN, 2000), and the median is close to the one found in other plants $(16$ plants, media $=46)$ (FELCMAN \& PEREIRA, 1998). The antidiabetic plants in which zinc may be important to their therapeutic properties (plants $1,3,4$, median $=82 \pm 38 \mu \mathrm{g} \mathrm{g}^{-1}$ dry wt) were compared with the other 30 plants (median $=33 \pm 12$ ), and indicate the possible 
importance of zinc in the claimed antidiabetic properties. Particularly, the aromatic plant Apium graveolens L. (plant 1) has a much higher concentration of this metal than the others. It should be mentioned that this plant has a very low chromium concentration (OSÓRIO E CASTRO, 1998), so, its therapeutic properties could be due, in principle, to the high content of zinc. Statistical comparison $(P=0.05)$ of these two groups proves significant differences. The other plants (plants 18, 19, 21, 30, 32 and 33) are also antidiabetic, but this property is attributed to their relatively high chromium content (FELCMAN \& TRISTÃo-BRAGANÇA, 1988; OSÓRIO E CASTRO, 1998).

Table 2

Chromium concentration in the studied plants (leaves from fruit trees and others)

\begin{tabular}{|c|c|c|c|}
\hline $\mathrm{N}^{\circ}$ & Common name & Scientific name & $\mu \mathrm{g} \mathrm{g}^{-1}$ dry wt \\
\hline $1^{\mathrm{a}}$ & Jambolan & Syzygium jambolanum L. & $7.5 \pm 0.85(n=10)$ \\
\hline $2^{\mathrm{a}}$ & Sea oak & Fucus vesiculosus $\mathrm{L}$. & $5.0 \pm 0.52(\mathrm{n}=6)$ \\
\hline 3 & Fig & Ficus carica $\mathrm{L}$. & $2.8 \pm 0.23(n=33)$ \\
\hline $4^{\mathrm{a}}$ & Blackberry & Rubus fruticosus $\mathrm{L}$. & $2.1 \pm 0.32(n=24)$ \\
\hline 5 & Hazelnut & Corylus avellana $\mathrm{L}$. & $2.1 \pm 0.23(n=21)$ \\
\hline $6^{\mathrm{a}}$ & Bean plant & Vigna unguiculata (L.) Walp & $2.0 \pm 0.15(\mathrm{n}=44)$ \\
\hline 7 & Plum & Prunus domestica $\mathrm{L}$. & $1.4 \pm 0.11(n=6)$ \\
\hline 8 & Strawberry tree & Arbutus unedo L. & $1.3 \pm 0.18(n=6)$ \\
\hline $9^{\mathrm{a}}$ & Strawberry & Fragaria vesca $\mathrm{L}$. & $1.3 \pm 0.17(n=13)$ \\
\hline 10 & Medlar (tree) & Eriobotrya japonica (Thunb.) Lindley & $1.1 \pm 0.26(n=21)$ \\
\hline 11 & Vine & Vitis vinifera $\mathrm{L}$. & $0.9 \pm 0.18(n=15)$ \\
\hline 12 & Cherry tree & Prunus avium $\mathrm{L}$. & $0.9 \pm 0.07(n=19)$ \\
\hline 13 & Melon & Cucumis melo $\mathrm{L}$. & $0.7 \pm 0.14(\mathrm{n}=18)$ \\
\hline 14 & Peach & Prunus persica $\mathrm{L}$. & $0.7 \pm 0.12(n=19)$ \\
\hline 15 & Apple & Malus Miller domestica Borkh. & $0.7 \pm 0.10(\mathrm{n}=15)$ \\
\hline 16 & Lemon & Citrus limon L. & $0.6 \pm 0.15(n=16)$ \\
\hline 17 & Quince & Cydonia oblonga Miller & $0.6 \pm 0.10(n=21)$ \\
\hline 18 & Orange & Citrus aurantium L. sinensis (L.) Osbeck & $0.6 \pm 0.08(\mathrm{n}=17)$ \\
\hline 19 & Pear & Pyrus communis L. & $0.5 \pm 0.10(\mathrm{n}=15)$ \\
\hline 20 & Olive & Olea europaea $\mathrm{L}$. & $0.4 \pm 0.15(n=18)$ \\
\hline 21 & Orange & Citrus aurantium L. amara (L.) Engler & $0.2 \pm 008(n=14)$ \\
\hline
\end{tabular}

a: antidiabetic plants. 
Table 3

Zinc concentration in the studied plants (aromatic plants (leaves) and others)

\begin{tabular}{|c|c|c|c|}
\hline $\mathrm{N}^{\circ}$ & Common name & Scientific name & $\mu \mathrm{g} \mathrm{g}^{-1}$ dry wt \\
\hline $1^{\mathrm{a}}$ & Celery & Apium graveolens L. & $135( \pm 16.5) \mathrm{n}=18$ \\
\hline 2 & Rock-rose & Cistus ladeniferus L. & $60( \pm 2.5) n=9$ \\
\hline $3^{\mathrm{a}}$ & Verbena & Verbena officinalis L. & $60( \pm 4.5) n=6$ \\
\hline $4^{\mathrm{a}}$ & Egypt stars & Coreopsis tinctoria Nutt. & $50( \pm 4.5) \mathrm{n}=9$ \\
\hline 5 & Herb of St. Robert & Geranium robertianum $\mathrm{L}$. & $50( \pm 6.0) n=15$ \\
\hline 6 & Coriander & Coriandrum sativum $\mathrm{L}$. & $50( \pm 3.0) \mathrm{n}=6$ \\
\hline 7 & Lavender & Lavandula stoechas L. & $48( \pm 6.5) n=9$ \\
\hline 8 & Tomato & Solanum lycopersicum L. & $45( \pm 2.0) n=9$ \\
\hline 9 & Broad bean & Vicia faba $\mathrm{L}$. & $42( \pm 2.0) n=6$ \\
\hline 10 & Grean bean & Phaseolus vulgaris $\mathrm{L}$. & $41( \pm 1.5) n=6$ \\
\hline 11 & Convolvulus & Convolvulus arvensis $\mathrm{L}$. & $41( \pm 3.0) n=9$ \\
\hline 12 & White broom & Cytisus scoparius L. & $40( \pm 1.0) \mathrm{n}=6$ \\
\hline 13 & Wild thyme & Thymus serpyllum $\mathrm{L}$. & $39( \pm 3.5) \mathrm{n}=9$ \\
\hline 14 & St. John's-wort & Hypericum androsaemun $\mathrm{L}$. & $37( \pm 1.0) \mathrm{n}=6$ \\
\hline 15 & Bean plant & Vigna unguiculata L. (Walp) & $35( \pm 6.5) n=12$ \\
\hline 16 & Fennel & Foeniculum vulgare Miller & $35( \pm 2.5) n=6$ \\
\hline 17 & Cypress & Cupressus sempervirens L. & $35( \pm 3.5) n=9$ \\
\hline $18^{\mathrm{a}}$ & Cow-foot & Bauhinia aculeata $\mathrm{L}$. & $35( \pm 2.5) n=9$ \\
\hline $19^{\mathrm{a}}$ & Knot-grass (pigveed) & Polygonum aviculare L. & $35( \pm 6.0) \mathrm{n}=10$ \\
\hline 20 & Carque & Pterospartum tridendatum $\mathrm{L}$. & $34( \pm 2.0) n=6$ \\
\hline $21^{\mathrm{a}}$ & White archangel & Lamium album $\mathrm{L}$. & $33( \pm 5.5) \mathrm{n}=6$ \\
\hline 22 & Eucaliptus & Eucalyptus L,Hér. globulus Labill. & $33( \pm 2.0) \mathrm{n}=9$ \\
\hline 23 & Heather & Erica arborea $\mathrm{L}$. & $32( \pm 2.5) \mathrm{n}=8$ \\
\hline 24 & Linden (leaves) & Tilia cordata Miller & $29( \pm 1.5) \mathrm{n}=6$ \\
\hline 25 & Linden (flowers) & Tilia cordata Miller & $26( \pm 1.0) \mathrm{n}=6$ \\
\hline 26 & Centaury & Centaurium Hill erythraea Rafn. & $25( \pm 3.0) \mathrm{n}=15$ \\
\hline 27 & Gromwell & Lithospermum L. diffusum Lag. & $23( \pm 4.5) n=12$ \\
\hline 28 & Rosemary & Rosmarinus officinalis L. & $20( \pm 1.5) n=6$ \\
\hline 29 & Heather & Erica umbelata $\mathrm{L}$. & $19( \pm 1.0) \mathrm{n}=8$ \\
\hline $30^{\mathrm{a}}$ & Whortleberry & Vaccinium myrtillus L. & $17( \pm 1.0) \mathrm{n}=6$ \\
\hline 31 & Salvia & Salvia officinalis L. & $16( \pm 3.0) n=9$ \\
\hline $32^{\mathrm{a}}$ & Brazil wood & Caesalpinia ferrea Mart. & $16( \pm 1.5) \mathrm{n}=12$ \\
\hline $33^{\mathrm{a}}$ & "Pedra H. Kaá" (Brazil) & Myrcia sphaerocarpa $\mathrm{L}$. & $8( \pm 2.0) n=7$ \\
\hline
\end{tabular}

a: antidiabetic plants.

Zinc concentration in leaves from 18 fruit trees were also determined (Table 4). Zinc concentrations are between 8 (plant 18) and $165 \mu \mathrm{g} \mathrm{g}^{-1}$ dry wt (plant 1) with a median $=37 \pm 38 \mu \mathrm{g} \mathrm{g}^{-1}$ dry wt, similar to the one found for plants reported in Table 3 . 
Plants 1 and 3 present pharmacological activity, and have zinc concentration, median = $115 \pm 50 \mu \mathrm{g} \mathrm{g}^{-1}$ dry wt, which is much higher than that of the other 16 plants $(27 \pm$ $21 \mu \mathrm{g} \mathrm{g}^{-1}$ dry wt). Statistical calculations $(\mathrm{P}=0.05)$ show that this difference is, indeed, meaningful. Particularly, the plant Passiflora (plant 1) shows a very high content of zinc compared with the others. It is known to have strong antidiabetic properties which could, in principle, be attributed to this metal. Its chromium content is too low (OSÓRIO E CASTRO, 1998) to be important as responsible for its therapeutic properties. The other plant, Fragaria vesca L. (plant 3), is also active and its zinc content is relatively high, which could, probably, explain its medicinal activity. The other type 2 antidiabetic plants (plants 12 and 18) have zinc concentration values much lower (19 and $8 \mu \mathrm{g} \mathrm{g}^{-1}$ dry wt, respectively) than the mean $\left(37 \pm 38 \mu \mathrm{g} \mathrm{g}^{-1}\right.$ dry wt); this fact may exclude zinc as the factor to explain their activity. Indeed, as was said before, chromium is a better candidate, due to its high relative concentrations (Table 2, plants 1 and 4).

Table 4

Zinc content in the studied plants (leaves from fruit trees)

\begin{tabular}{|c|c|c|c|}
\hline $\mathrm{N}^{\circ}$ & Common name & Scientific name & $\mu \mathrm{g} \mathrm{g}^{-1}$ dry wt \\
\hline $1^{\mathrm{a}}$ & Passion flower & Passiflora $\mathrm{L}$. & $165( \pm 4.6) n=18$ \\
\hline 2 & Medlar (tree) & Eriobotrya japonica (Thumb.) Lindley & $90( \pm 6.5) n=12$ \\
\hline $3^{\mathrm{a}}$ & Strawberry & Fragaria vesca $\mathrm{L}$. & $65( \pm 2.0) n=6$ \\
\hline 4 & Hazelnut & Corylus avellana $\mathrm{L}$. & $60( \pm 3.5) n=10$ \\
\hline 5 & Melon & Cucumis melo $\mathrm{L}$. & $40( \pm 3.5) n=6$ \\
\hline 6 & Fig & Ficus carica $\mathrm{L}$. & $34( \pm 4.5) n=15$ \\
\hline 7 & Strawberry tree & Arbutus unedo L. & $29( \pm 4.5) \mathrm{n}=6$ \\
\hline 8 & Olive & Olea europaea $\mathrm{L}$. & $27( \pm 2.0) \mathrm{n}=6$ \\
\hline 9 & Pear & Pyrus communis $\mathrm{L}$. & $25( \pm 3.5) n=13$ \\
\hline 10 & Almond & Amygdalus communis L. & $21( \pm 3.5) n=6$ \\
\hline 11 & Orange & Citrus aurantium L. sinensis L. & $19( \pm 4.5) \mathrm{n}=12$ \\
\hline $12^{\mathrm{a}}$ & Blackberry & Rubus fruticosus $\mathrm{L}$. & $19( \pm 3.0) \mathrm{n}=14$ \\
\hline 13 & Lemon & Citrus limon $\mathrm{L}$. & $17( \pm 3.0) \mathrm{n}=11$ \\
\hline 14 & Plum & Prunus domestica $\mathrm{L}$. & $16( \pm 2.0) n=6$ \\
\hline 15 & Persimmon (dule-plum) & Diospyros L. & $12( \pm 1.5) \mathrm{n}=6$ \\
\hline 16 & Vine & Vitis vinifera $\mathrm{L}$. & $11( \pm 1.5) n=6$ \\
\hline 17 & Apple & Malus L. domestica Borkh & $9( \pm 1.5) \mathrm{n}=6$ \\
\hline $18^{\mathrm{a}}$ & Jambolan (Brazil) & Syzygium jambolanum $\mathrm{L}$. & $8( \pm 3.5) n=11$ \\
\hline
\end{tabular}

a: antidiabetic plants 


\section{Conclusions}

More than 400 plants with suspected glucose-lowering potential are known (BAYLEY \& DAY, 1989) and today hypoglycaemic plant remedies are still prevalent in the third world countries where they have been in use, in most cases for centuries. In western nations, however, such traditional treatments are also experiencing a remarkable come back (EISEMBERG et al., 1993).

There are many organic compounds isolated and identified from plants that previously demonstrated to have hypoglycaemic properties, which are claimed to be due to glycanes, proteins, flavonoids, steroids, triterpenoids, alkaloids, etc. (PEREZ et al., 1998).

It is well known that chromium and zinc are important minerals and are also related to the glucose metabolism. Chromium has been known as an essential mineral for at least 30 years. Its beneficial role is well documented in human health maintenance and its deficiency has been linked with increased incidence of age-related non-insulin diabetes. The beneficial dietary form of $\mathrm{Cr}$ is an organometalic compound called glucose tolerance factor which consists of an ion of $\mathrm{Cr}^{3+}$ bound to several molecules of niacin and probably glutamic acid, glycine and cysteine. Without $\mathrm{Cr}^{3+}$ at its core, GTF is inactive (SCHWARTZ \& MERTZ, 1959). About zinc no metalocompound has been isolated but its role in the synthesis, secretion and activity of insulin is well known (KING \& KEEN, 1994).

Chromium and zinc deficiency can be caused by inadequate nutrition and age (KING \& KEEN, 1994; ANDERSON, 1992). Chromium and zinc contents of individual foods vary widely, and are dependent on the introduction of metals in the growing, transport, processing and fortification of the food. Even well-balanced diets may contain insufficient quantities of chromium (ANDERSON, 1992), which can promote marginal chromium states. Thus, it is possible that teas, alcoholic extracts, or powders prepared from plants with relatively high concentrations of these metals, can complement the diet of healthly or diabetic people.

Some of the analysed plants have already been claimed to have therapeutic properties for diabetic people (non-insulinic diabetes) as referred to above. Perhaps others can be used for that purpose, taking into account their content in zinc and/or chromium. The former have been used with success as teas, alcoholic concentrates or powders, but no studies with animals or humans have been published, except for their mention as antidiabetic plants (OLIVEIRA-FEIJÃO, 1952; FOREY \& LINDSAY, 1997), and in oral reports of patients. It remains to be determined if chromium or zinc have any relation to the medical properties of these plants. However, it is known that chromium supplemented to diets reverses symptoms of non-insulin dependent diabetes in laboratory animals and humans (ANDERSON, 1998) and that chromium is better 
absorbed in some compounds than in its inorganic state (MERTZ, 1983). It must be complexed with certain ligands to be fully active (TOEPFLER et al., 1977; VINCENT, 1993). It may also be the case that plants with relatively high concentration of chromium with no antidiabetic properties (plants 3 and 5, table 2), form organic complexes not adequate to be active. Concerning zinc, this has been given as a supplement in drinking water with good results on insulin activity (MING-DER et al., 1998), so the plants that contain this metal in relatively high concentrations may due their therapeutic activity to it.

Although it is not proved that therapeutic properties for these plants are due to chromium and/or zinc, these metals should be considered important as they can be used by the plant to produce organometalic compounds, which could be the biologically active molecules.

In conclusion, these results suggest that plants used in Portugal as active agents to alleviate non-insulinic diabetes may have such an activity owing to their high levels of the analysed metals, which should be in a complex form with organic compounds, so as to have the best therapeutic effect.

The technical assistance for the spectrophotometric readings, performed by Tech. Eng. C. VITORINO, is strongly recognized.

\section{References}

ADRIAN, J. (1991): Le chrome des produits alimentaires: origine et teneurs. Sci. Aliments, 11, 417-464. ANDERSON, R. A. (1992): Chromium, glucose tolerance and diabetes. Biol. Trace Element Res., 32, 19-24. ANDERSOn, R. A. (1998): Chromium, glucose intolerance and diabetes. J. Am. Coll. Nutr., 17(6), 548-555. Anderson, R. A., Bryden, N. A. \& Polansky, M. (1992): Dietary chromium intake, freely chosen diets, institutional diets, and individual foods. Biol. Trace Element Res., 32, 117-121.

BAYLEY, C. J. \& DAY, C. (1989): Traditional plant medicines as treatments for diabetes. Diab. Care, 12, $553-564$.

Curtius, A. J. \& CAmpos, C. C. (1982): Distribuição de metais em cana de açúcar. (Metal distribution in sugar cane.) Anais da Acad. Bras. de Ciências, 34(4), 663-668.

Eisemberg, D. M., Kessler, R. C., Foster, C., Norloek, F. E., Calkins, D. R. \& Delbanco, T. L. (1993): Unconventional medicine in the United States. N. Eng. J. Med., 328, 246-252.

Felcman, J. \& PereirA, C. E. P. (1998): Correlation between five minerals and the healing effect of Brazilian medicinal plants. Biol. Trace Element Res., 65, 251-259.

Felcman, J. \& Tristão-BragançA, M. L. (1988): Chromium in plants. Comparison between the concentration of chromium in Brazilian nonhypo and hypoglycemic plants. Biol. Trace Element Res., $17,11-16$. 
FOREY, P. \& LindSAY, R. (1997): Plantas medicinais. (Medicinal plants). Plátano edições técnicas, Lisbon, pp. $1-126$.

King, J. C. \& KeEn, C. L. (1994): Zinc. -in: ShILs, M. E., Olson, J. A. \& SHIKE, M. (Eds). Modern nutrition in health and disease. 8th ed, Lea \& Febiger, Philadelphia, pp. 214-230.

MAHDI, G. S. \& NAISMITH, D.J. (1991): Role of chromium in barley in modulating the symptoms of diabetes, Ann. Nutr. Metabol., 35, 65-70.

MERTZ, W. (1983): Chromium: An ultra-trace element. Chemica Scripta, 21, 145-150.

Ming-Der, C., Shy-Jane, L., Pi-YaO, L., Yang, V. C., Alexander, P. S. \& Wen-Han, L. (1998): Effects of zinc supplementation in the plasma glucose level and insulin activity in genetically obese (ob/ob) mice. Biol. Trace Element Res., 61, 303-311.

OLIVEIRA FeIJÃo, R. D. (1952): Medicina pelas plantas. (Medicine by plants.) Livraria Progresso Editora, Lisbon, pp. 1-334.

OSÓRIO E CASTRO, V. R. (1998): Chromium in a series of Portuguese plants used in the herbal treatment of diabetes. Biol.Trace Element Res., 62, 101-106.

Perez, R., Zavala, M., Perez, M. A. S. \& Perez, C. (1998): Antidiabetic effect of compounds isolated from plants. Phytomedicine, 5, 55-75.

SchwARTZ, K. \& MERTZ, W. (1959): Chromium (III) and the glucose tolerance factor (letters to the editors). Arch. Biochem. Biophys., 85, 292-295.

SzentminÁlyi, K. \& Then, M. (2000): Teas of Equiseti herba, Myrtilli folium and Salviae folium. Acta Alimentaria, 29, 43-49.

Toepfler, E. W., Mertz, W., Polansky, M. M., Roginski, E. E. \& Wolf, W. R. (1977): Preparation of chromium-containing material of glucose tolerance factor activity from brewers yeast extracts and synthesis. J. agric. Fd. Chem., 25, 162-166.

VINCENT, J. V. (1993): Low-molecular-weight chromium-binding substance synthetic models. J. inorg. Biochem., 51, 77-77. 